\title{
Innate immunity in the small intestine
}

\author{
Rebeca Santaolalla, Masayuki Fukata, and Maria T. Abreu* \\ Division of Gastroenterology, Department of Medicine, University of Miami Miller School of \\ Medicine, Miami, FL
}

\begin{abstract}
Purpose of review-In this article, we provide an update of the latest findings related to the innate immunity in the small intestine. In particular, we will focus on innate immune receptors and antimicrobial strategies that keep luminal bacteria and viral pathogens under control to avoid mucosal damage. These strategies include IgA secretion and antimicrobial peptides produced by Paneth cells, and downregulation or anergy of the innate immune receptors themselves.

Recent findings-Pattern-recognition receptors are the main target in the study of innate immunity in the intestinal mucosa due to their involvement in the regulation of host-commensal interactions. It has been shown that TLR5 deficient mice develop metabolic syndrome and have altered intestinal microbiota. On the other hand, NOD2 has been associated in the activation of autophagy and the inhibition of TLR4. Moreover, NOD2 has been described to be essential to keep a feedback loop in the host-commensal homeostasis, through the kinase Rip-2.
\end{abstract}

Summary-Innate immunity in the small intestine is mainly characterized by IgA secretion and Paneth cell antimicrobial function. In both cases pattern recognition receptors, TLRs and NLRs, are involved. A better understanding of the innate immunity in the small intestine would provide valuable information to develop vaccines against pathogens.

\section{Keywords}

Innate immunity; TLR; NLR; Paneth cells; IgA

\section{Introduction. The small intestine}

The small intestine is the longest organ in our body, and it is where the most important part of digestion takes place. The adult small intestine measures about 16 feet and has a diameter of 1 inch-although its villi and microvilli increase its absorptive surface 500 times. The small intestine has three differentiated parts: duodenum, jejunum and ileum; where the absorption of nutrients takes place. The epithelium of the small intestine is continuously in contact with food antigens, the enteric commensal bacteria, and potential pathogens that enter the host through the diet. The bacterial load in the small intestine is low and it increases distally. To keep the bacterial count low, the small intestine employs its motility to sweep bacteria along, mucus, and antibacterial molecules secreted in the gastric acid, biliary juice, as well as substances produced by the commensal microflora and epithelial cells, such as Paneth cells. In this manuscript we will review the latest findings on innate immunity of the small intestine, giving special attention to the innate immune receptors and antimicrobial secretions that keep the bacteria under control to avoid mucosal damage.

"Correspondence: Maria T. Abreu, MD, Division of Gastroenterology, Department of Medicine, University of Miami Miller School of Medicine, PO Box 016960, Miami, FL, 33101, MAbreu1@ med.miami.edu, TEL: 305-243-5121, Fax: 305-243-6125. 


\section{Mucosal immunity and homeostasis in the small intestine}

The first layer of defense against pathogens in the intestinal mucosa is the epithelium that faces the luminal surface of the intestinal tract. It is composed of four cell lineages that come from a common stem cell progenitor: absorptive enterocytes, mucus-producing goblet cells, hormone-producing enteroendocrine cells, and Paneth cells, which produce antimicrobial peptides (Figure 1). Underneath the epithelium, there is the lamina propria, where the immunocompetent cells are found. Macrophages and dendritic cells are largely responsible for the innate immune response in the mucosa. Dendritic cells are sitting below the intestinal epithelium but their cytoplasmic extensions are interdigitated among the epithelial cells in order to sample the luminal contents and present antigens to $\mathrm{T}$ cells, in the lamina propria and underlying lymphoid follicles. ${ }^{1,2} \mathrm{~T}$ and $\mathrm{B}$ cells and Peyer's Patches form the adaptive immune system. However, in the intestinal milieu the separation of adaptive and innate immune responses is not worth making since there is an intimate relationship with the commensal microbiota.

Initiation of the innate immune response is triggered by recognition of pathogen-associated molecular patterns (PAMPs) by pathogen-recognition receptors (PRRs). The most studied PRRs are the toll-like receptors (TLRs) which are localized either in the cell surface or within endosomes and can be expressed by intestinal epithelial cells, macrophages, dendritic cells, B and T cells and stromal cells. Cytoplasmic PRRs include the RNA helicase family (retinoic acid inducible gene protein 1 or RIG-1, and melanoma differentiation-associated gene or MDA5) and the nucleotide-binding and oligomerization domain (NOD)-like receptor (NLR) family. ${ }^{3}$

\section{Toll-like receptors and their expression in the intestine}

Toll-like receptors (TLR) are transmembrane proteins that recognize evolutionary conserved patterns present in microorganisms. These receptors are typically expressed in the intestinal epithelial cells either on the cell surface or endosomes, as well as in other immunocompetent cells in the lamina propria, and they activate the innate immune response characterized by $\mathrm{NF}-\mathrm{\kappa B}$ activation, cytokine production, and chemokine-medicated recruitment of acute inflammatory cells.

TLR signaling in the intestine has been shown to be involved in epithelial cell proliferation, ${ }^{4,5} \operatorname{IgA}$ production, ${ }^{6}$ maintenance of tight junctions ${ }^{7}$ and antimicrobial peptide expression - which are functions that are crucial for keeping a healthy epithelial barrier. ${ }^{8}$ Because of the close proximity and high density of PAMPs in the intestinal lumen, a variety of mechanisms have evolved to protect against deregulated TLR-mediated inflammation in the absence of pathogens. First of all, conditions in the small intestine are inherently different from those in the colon. The density of bacteria increases from $10^{2}$ bacteria in the proximal small intestine to $10^{8}$ in the distal ileum, and $10^{12}$ in the colon. The differences in bacterial load along the intestine and the antimicrobial environment in the bottom of the small intestine crypts kept by Paneth cells may influence the regional differences in the expression of TLRs. Other mechanisms to keep the intestinal bacteria under control are polarized expression of TLRs, induction of tolerance by PAMPs, expression of TLR inhibitory molecules, and the homeostatic function of bacterial-epithelial interactions. ${ }^{9}$ TLR1, TLR2, TLR3, TLR4, TLR5 and TLR9 have been detected in the intestinal epithelial cells of the human small intestine but their function in vivo has primarily been ascertained by knock-out studies. ${ }^{10}$ Smythies and colleagues recently described that human intestinal macrophages are anergic to TLR ligands present in the commensal bacteria. ${ }^{11}$ The majority of intestinal macrophages expressed TLR3, TLR5, TLR7, TLR8 and TLR9, while a smaller subset expressed TLR4 and TLR6, but do not secrete pro-inflammatory cytokines in 
response to TLR ligands. Moreover, intestinal macrophages do not express MD-2, which make them unresponsive to LPS. In addition, the expression of MyD88 was also lower in these cells.

\section{NOD proteins}

Nucleotide-binding oligomerization domain (NOD) proteins are another class of innate receptors that recognize PAMPs. Crohn's disease is known to be a consequence of an uncontrolled inflammatory response to the commensal microbiota and several innate immune susceptibility genes, including NOD2 mutations, have been identified. ${ }^{12}$ Although Crohn's disease can affect any part of the gastrointestinal tract, the most common presentation is chronic inflammation of the ileum. NOD1 is expressed by intestinal epithelial cells and is required for recognition of invasive Gram-negative bacteria. ${ }^{13,14}$ The specific ligand recognized by NOD1 is found only in Gram-negative bacterial peptidoglycan. In addition to TLRs, invasive organisms may elicit an innate immune response from intestinal epithelial cells through intracellular NOD1. Gut-associated lymphoid tissue (GALT) (tonsils, lymphoid aggregates in colon, stomach, esophagus and appendix, Peyer's patches) is induced by the presence of Gram-negative commensal bacteria through NOD1 signaling. ${ }^{15}$

The ligand for NOD2, also called CARD15 (C-terminal caspase recruitment domain 15), is muramyl dipeptide (MDP) derived from peptidoglycan common to both Gram-positive and Gram-negative bacteria. NOD2 is highly expressed in monocytes and Paneth cells. ${ }^{16}$ The work of Kobayashi et al. using NOD2 deficient mice and testing their response to MDP and other agonists, ${ }^{17}$ as well as Maeda's,${ }^{18}$ led to a model of inflammatory bowel disease in which Paneth cells, dendritic cells and macrophages protect the host from intestinal infection via NOD-2 mediated release of cryptidins and proinflammatory cytokines. Defects in NOD2 could result in decreased bacterial clearance. Interestingly, the same group recently showed that NOD2 deficient mice have more commensals in their gut and are less effective at clearing the newly colonizing bacteria than wild-type mice. ${ }^{19}$ They found that ileal crypts from wild-type mice have better bacteria-killing activity through NOD2 stimulation. NOD2 is required for the secretion of antimicrobial peptides but its deletion does not interfere with the normal development of Paneth cells. They also found that the expression of NOD2 and the Rip2 kinase are dependent on the commensal flora; while the expression of adaptor molecules for TLRs, MyD88 and Tirap/Mal was independent.

Hugot and colleagues recently described how NOD2 regulates host response towards the commensal bacteria. ${ }^{20}$ NOD2 deficient mice exhibit an increased translocation of bacteria through Peyer's patches in the ileum compared to wild-type mice. This increased permeability in Peyer's patches was triggered by $\mathrm{CD} 4+\mathrm{T}$ cells and IFN $\gamma$ production. Oral administration of antibiotics reversed this phenotype, as well as treatment with anti-CD4 and anti-IFN monoclonal antibodies. This study demonstrates that NOD2 regulates the cross-talk between T-cells and the intestinal epithelium, and downregulates the pro-inflammatory effect induced by the ileal commensals, most likely through inhibition of TLR signaling.

\section{NLRs and the inflammasome}

The NLRs (nucleotide-binding domain leucine-rich repeat-containing receptors) are also innate immune receptors, and the first identified NLRs were NOD1 and NOD2. These receptors have a common structure of a central nucleotide-binding domain called NACHT, which is located between the C-terminal LRR (leucine-rich repeat) domain and the $\mathrm{N}$ terminal domain. There are different sub-groups of NLRs defined by their N-terminal domain: caspase-recruitment domain CARD (NLRC), pyrin domain PYD (NLRP), or baculovirus IAP repeat BIR (NAIP). Several NLRs can assemble multimolecular complexes 
in response to different stimuli, leading to the activation of inflammatory caspases, such as caspase-1. By analogy to the apoptosome, which activates apoptosis-inducing caspases, the NLR multimolecular complexes are called inflammasomes and they activate caspases necessary for propagating inflammatory signals. ${ }^{21-23}$

The NLPR3 inflammasome, also called NALP3, has been the most studied member of the NLPR family. NLPR3 recruits the adaptor ASC and caspase-1 to form a proteolytic complex that cleaves pro-IL- $1 \beta$ and pro-IL-18 into their mature and secreted forms. NLPR3 genetic variants were first described in Crohn's disease subjects from Belgium and Canada, ${ }^{24}$ as well as in Swedish cohorts. ${ }^{25}$ but not in the UK. ${ }^{26}$ The conflicting results may be explained by the presence of genetic variants in other components of the NALP3 inflammasome, including NOD2. ${ }^{27}$

\section{Intestinal Ig A secretion}

GALT plays another important role in the intestinal mucosa through B cell production of IgA that is released into the lumen through the epithelium, providing protection against microbes. IgA deficiency is common and puts patients at risk for chronic giardiasis. Thus, in the face of defective innate immune function there can be pathogens that can cause chronic infections. We showed that a constitutively active TLR4 that is only expressed in the intestinal epithelium (driven by the villin promoter) of mice, promotes the production of $\operatorname{IgA}$ in the small intestine, ${ }^{6}$ by an increase of $\mathrm{B}$ cell recruitment to the lamina propria and class switching of B cells to $\operatorname{IgA}$. This increase of secretory $\operatorname{IgA}$ is useful to neutralize pathogenic bacteria and control commensals, in order to keep intestinal homeostasis. These data extend the work of Andrea Cerutti who demonstrated that TLR stimulated IECs produced APRIL that promotes class switching to $\operatorname{IgA} 2$, a type of $\operatorname{IgA}$ that is antigen non-specific but more resistant to hydrolysis and therefore perfect for the intestinal environment $28,29$.

The production of IgA is very clearly dependent on the microbiota and changes in the composition of the flora can alter the IgA pattern. ${ }^{30}$ Moreoever, there is a threshold of IgA production based on the density of the flora with counts needed between $10^{8}$ and $10^{9}$ bacteria needed for optimal IgA production.

\section{Paneth cells and defensins: keeping the balance between the host and its microbiota}

Paneth cells are present at the base of crypts in the entire small intestine, with an increase in their number as one goes more distally, reaching the highest concentration in the terminal ileum. These specialized secretory cells are located in the base of the crypts of Lieberkühn and are the major producers of antimicrobial proteins in the small intestine. Paneth cells produce and secrete lysozyme (also present in tears and saliva), secretory phospholipase A2, the C-lectin RegIII $\gamma$ (human counterpart HIP/PAP), as well as a-defensins (also called cryptidins in mice) and angiogenin- 4 - these last two, are exclusively produced by this cell type. In addition to $a$-defensins expressed by Paneth cells, IEC express $\beta$-defensins.

It has been shown that Paneth cells have an autonomous mechanism to detect potentially invasive bacteria. Paneth cells express PRRs, specifically NOD2 and TLR2, 4, 5 and $9,16,31-33$ and signaling through these can induce the secretion of antimicrobial proteins and lectins. ${ }^{34,}{ }^{35}$ Furthermore, Hooper's group described that Paneth cells sense enteric bacteria through MyD88. ${ }^{36}$ Gong et al. demonstrated that blocking the MyD88 pathway in the intestinal epithelium causes spontaneous inflammation, and this is due to decreased Paneth cell-derived a-defensins and RegIII $\gamma \cdot{ }^{37}$ Thus, inflammation in the intestine is linked to a defect in innate immune signaling. 
Autophagy is an evolutionarily conserved mechanism that eukaryotic cells use to recycle proteins and organelles, as well as to clear intracellular pathogens. Normal Paneth cell function is critically dependent on autophagy because these cells have such a high production of secreted proteins. Sequence variants of ATG16L1 and IRGM1, two autophagy-related genes, are associated with Crohn's disease. ${ }^{38-40}$ Subsequently, Stappenbeck's group discovered that loss of function of ATG1L1 showed defects in the secretory function of Paneth cells in mice. Furthermore, Crohn's disease patients, who were homozygous for the ATG16L1 susceptibility allele, had autophagy defects in Paneth cells in the ileum. ${ }^{41,42}$ NOD1 and NOD2 have been also associated with autophagy. Travassos et al. recently described a mechanism by which NOD1 and NOD2 recruit the protein ATG16L1 to the plasma membrane at the bacterial entry site. ${ }^{43}$ NOD1 agonists induce autophagy in Hela cells and MDP, the NOD2 ligand, stimulates autophagy in bone marrow-derived macrophages from wild-type mice, but not NOD2 deficient mice. The authors describe for the first time a functional link between NOD2 and ATG16L1, which is interesting as polymorphisms in both of them have been associated with Crohn's disease.

On another note, it has recently been described that interleukin-17A, which is constitutively expressed in GALT and epithelial cells of the small intestine, plays a protective role against the first stages of Salmonella typhimurium infection in mice. ${ }^{44}$ This group, and others, ${ }^{45}$ showed that IL-17A is constitutively expressed in CD4+ T cells present in the lamina propria of the small intestine as well as Peyer's patches and mesenteric lymph nodes. In addition, IL-17A regulates the expression of $\beta$-defensin 3 in the intestinal epithelium, which can effectively kill $S$. typhimurium before it invades the mucosa.

\section{TLR function in the intestine. Learning from animal models}

The use of knock-out and transgenic mice to study the TLR pathway has been of enormous importance in the study of innate immunity in the gut. Knock-out mice studies have demonstrated the involvement of TLRs in the protection of the intestinal mucosa from epithelial injury. Transgenic mice that carry a dominant-negative MyD88 under the epithelial-specific villin promoter have spontaneous inflammation in the small intestine, indicating immunoregulatory roles of TLR signaling in the intestine. ${ }^{37}$ Oral administration of dextran sodium sulfate (DSS) results in epithelial injury and exposure of the lamina propria to luminal bacteria. Several authors have shown that administration of DSS to TLR4, TLR2 and MyD88 knock-out mice induces high mortality compared with wild-type mice. Administration of broad spectrum antibiotics to wild-type mice has a similar deleterious effect as MyD88 deficiency, suggesting that stimuli provided by luminal bacteria via TLR signaling protect against DSS damage. However, there is always the other side of the coin. TLRs can also lead to pathology, if they are activated tonically. In the mouse model with constitutively active TLR4 in the intestinal epithelium, DSS injury elicits a potent inflammatory response that can be fatal and increases the risk of colitis associated cancer. These animals produce increased levels of TNF- $\alpha$ and inflammatory mediators such as COX-2 in the small intestine. ${ }^{5}$

In addition to the role of TLRs in immune defense and repair of the gut, TLRs may also play a role in metabolism. Vijay-Kumar and colleagues demonstrated that TLR5 knockout mice develop metabolic syndrome and have altered gut microbiota. ${ }^{46}$ TLR5 deficient mice have a particular commensal microflora that makes them develop insulin resistance leading to hyperphagia, obesity, hyperglycemia and elevated levels of proinflammatory cytokines. This important finding adds information to the novel idea that TLRs are involved in the regulation of metabolism, most likely due to changes in the intestinal microbiota. 


\section{Necrotizing enterocolitis}

Another question related to the expression of TLRs is when they are expressed during development. This is an important concept as we are born without the presence of commensal bacteria in the gut, and the intestinal mucosa has to mature and become colonized by bacteria in the next first weeks after birth. Moreover, newborns are the most affected by necrotizing enterocolitis (NEC). NEC is diagnosed mainly in premature newborns who suffer bowel necrosis, more frequently in the ileocecal region. It is believed to occur because of an immature immune response against intestinal bacterial colonization. Buurman and colleagues have recently described that the immature neonatal gut does not express MD-2, neither in epithelial cells nor the lamina propria. Similarly, MD-2 is absent in the preterm infants with NEC. However, MD-2 was expressed in Paneth cells in the ileum of healthy term neonates and adults. This suggests that MD-2 expression, and consequently TLR4 signaling, depends on developmental regulation and colonization. ${ }^{47}$

Hackam et al. have described an inhibitory interaction between TLR4 and NOD2 using knock-out mice. ${ }^{48}$ TLR4 activation leads to apoptosis in the small intestine of newborns with NEC but not colon of adult mice, and its expression is dependent on NOD2. The authors found that NOD2 activation limits TLR4 signaling in enterocytes both in vivo and in vitro. Stimulation of NOD2 limits NEC by protecting against TLR4-mediated apoptosis. This interesting study proposes that NOD2 inhibits TLR4-mediated apoptosis through the mitochondrial protein SMAC-diablo, an inhibitor of IAPs (inhibitor-of-apoptosis proteins).

\section{Pathogenic bacteria}

Little is known about the intestinal innate immune response to pathogens. The main reason for this knowledge gap is the relative paucity of well-established animal models of infectious enterocolitis that mimic human disease. Most foodborne pathogens that cause enterocolitis and epidemics are Gram-negative pathogens and they have an ability to evade host immune recognition especially by blocking some of the key signaling pathways driven by TLRs. These facts highlight the importance of the innate immunity, especially PRRs that recognize Gram-negative pathogens like TLR4 in intestinal host defense mechanism against pathogenic infection. For instance, it seems that TLR4 adaptors (MyD88 and TRIF) play an indispensable role in the host response to enteric infection by Salmonella typhimurium. ${ }^{49}, 50$ Recognition of bacterial flagellin by TLR5 may have distinct role in host response to pathogenic infection. A unique subset of lamina propria dendritic cells (DCs) that express CD11c(hi), CD11b(hi), TLR5 but not TLR4 has been identified as an important host immune defense property. ${ }^{51}$ These DCs promote antigen non-specific IgA secretion and Th17 immune response in the intestine. Better understanding of cell type specific roles of individual TLR signaling will facilitate the establishment of novel strategy to manage enteric pathogenic infection and thus prevention of epidemics.

\section{Conclusion}

Given the surface area of the small intestine, a strong innate immune response must protect against potential pathogens. It must do so without eliciting such a strong response that nutrition is interfered with. The overarching theme is that innate immunity in the small intestine is characterized by $\operatorname{IgA}$ production and Paneth cell secretion of antimicrobial peptides. In both of these situations, TLRs and NLRs are involved. Although IgA may be antigen-specific, in fact, $\mathrm{T}$ cell independent, antigen-non-specific IgA can protect against both pathogens as well as commensals that get too close to the epithelium. We now know that TLR activation of epithelial cells is key to IgA secretion in the small intestine. Some data does suggest that TLR and NLR signaling by epithelial cells are important in defense 
against pathogens and in their absence the flora is changed. An understanding of innate immunity in the intestine can be leveraged to improve vaccine development and protect against pathogens.

\section{References}

1. Rescigno M. CCR6(+) dendritic cells: the gut tactical-response unit. Immunity. 2006; 24:508-10. [PubMed: 16713968]

2. Niess JH, Brand S, Gu X, Landsman L, Jung S, McCormick BA, Vyas JM, Boes M, Ploegh HL, Fox JG, Littman DR, Reinecker HC. CX3CR1-mediated dendritic cell access to the intestinal lumen and bacterial clearance. Science. 2005; 307:254-8. [PubMed: 15653504]

3. Fukata M, Vamadevan AS, Abreu MT. Toll-like receptors (TLRs) and Nod-like receptors (NLRs) in inflammatory disorders. Semin Immunol. 2009; 21:242-53. [PubMed: 19748439]

4. Fukata M, Chen A, Klepper A, Krishnareddy S, Vamadevan AS, Thomas LS, Xu R, Inoue H, Arditi M, Dannenberg AJ, Abreu MT. Cox-2 is regulated by Toll-like receptor-4 (TLR4) signaling: Role in proliferation and apoptosis in the intestine. Gastroenterology. 2006; 131:862-77. [PubMed: 16952555]

5. Fukata M, Hernandez Y, Conduah D, Cohen J, Chen A, Breglio K, Goo T, Hsu D, Xu R, Abreu MT. Innate immune signaling by Toll-like receptor-4 (TLR4) shapes the inflammatory microenvironment in colitis-associated tumors. Inflamm Bowel Dis. 2009; 15:997-1006. [PubMed: 19229991]

6. Shang L, Fukata M, Thirunarayanan N, Martin AP, Arnaboldi P, Maussang D, Berin C, Unkeless JC, Mayer L, Abreu MT, Lira SA. Toll-like receptor signaling in small intestinal epithelium promotes B-cell recruitment and IgA production in lamina propria. Gastroenterology. 2008; 135:529-38. [PubMed: 18522803]

7. Cario E, Gerken G, Podolsky DK. Toll-like receptor 2 enhances ZO-1-associated intestinal epithelial barrier integrity via protein kinase C. Gastroenterology. 2004; 127:224-238. [PubMed: 15236188]

8**. Hooper LV, Macpherson AJ. Immune adaptations that maintain homeostasis with the intestinal microbiota. Nat Rev Immunol. 2010; 10:159-69. Well written review on the host-microorganism interaction in the gut. This manuscript discusses the strategies of the intestinal immune system to keep under control the commensal microbiota. [PubMed: 20182457]

9. Abreu MT, Fukata M, Arditi M. TLR signaling in the gut in health and disease. J Immunol. 2005; 174:4453-60. [PubMed: 15814663]

10. Abreu MT. Toll-like receptor signalling in the intestinal epithelium: how bacterial recognition shapes intestinal function. Nat Rev Immunol. 2010; 10:131-44. [PubMed: 20098461]

11*. Smythies LE, Shen R, Bimczok D, Novak L, Clements RH, Eckhoff DE, Bouchard P, George $\mathrm{MD}, \mathrm{Hu} \mathrm{WK}$, Dandekar S, Smith PD. Inflammation anergy in human intestinal macrophages is due to Smad-induced IkappaBalpha expression and NF-kappaB inactivation. J Biol Chem. 2010; 285:19593-604. Interesting study describing how human macrophages isolated from the small intestine become tolerant to TLR ligands. [PubMed: 20388715]

12. Baumgart DC, Carding SR. Inflammatory bowel disease: cause and immunobiology. The Lancet. 2007; 369:1627-1640.

13. Girardin SE, Boneca IG, Carneiro LA, Antignac A, Jehanno M, Viala J, Tedin K, Taha MK, Labigne A, Zahringer U, Coyle AJ, DiStefano PS, Bertin J, Sansonetti PJ, Philpott DJ. Nod1 detects a unique muropeptide from gram-negative bacterial peptidoglycan. Science. 2003; 300:1584-7. [PubMed: 12791997]

14. Kim JG, Lee SJ, Kagnoff MF. Nod1 Is an Essential Signal Transducer in Intestinal Epithelial Cells Infected with Bacteria That Avoid Recognition by Toll-Like Receptors. Infect Immun. 2004; 72:1487-1495. [PubMed: 14977954]

15. Bouskra D, Brezillon C, Berard M, Werts C, Varona R, Boneca IG, Eberl Gr. Lymphoid tissue genesis induced by commensals through NOD1 regulates intestinal homeostasis. Nature. 2008; 456:507-510. [PubMed: 18987631] 
16. Lala S, Ogura Y, Osborne C, Hor SY, Bromfield A, Davies S, Ogunbiyi O, Nuñez G, Keshav S. Crohn's disease and the NOD2 gene: a role for paneth cells. Gastroenterology. 2003; 125:47-57. [PubMed: 12851870]

17. Kobayashi KS, Chamaillard M, Ogura Y, Henegariu O, Inohara N, Nunez G, Flavell RA. Nod2dependent regulation of innate and adaptive immunity in the intestinal tract. Science. 2005; 307:731-4. [PubMed: 15692051]

18. Maeda S, Hsu LC, Liu H, Bankston LA, Iimura M, Kagnoff MF, Eckmann L, Karin M. Nod2 mutation in Crohn's disease potentiates NF-kappaB activity and IL-1beta processing. Science. 2005; 307:734-8. [PubMed: 15692052]

19*. Petnicki-Ocwieja T, Hrncir T, Liu YJ, Biswas A, Hudcovic T, Tlaskalova-Hogenova H, Kobayashi KS. Nod2 is required for the regulation of commensal microbiota in the intestine. Proc Natl Acad Sci U S A. 2009; 106:15813-8. The authors describe here how NOD2 deficient mice have more commensals in their ileum and have an impaired ability to clear bacteria. [PubMed: 19805227]

20. Barreau F, Madre C, Meinzer U, Berrebi D, Dussaillant M, Merlin F, Eckmann L, Karin M, Sterkers G, Bonacorsi S, Lesuffleur T, Hugot JP. Nod2 regulates the host response towards microflora by modulating $\mathrm{T}$ cell function and epithelial permeability in mouse Peyer's patches. Gut. 2010; 59:207-17. [PubMed: 19837677]

21. Pedra JH, Cassel SL, Sutterwala FS. Sensing pathogens and danger signals by the inflammasome. Curr Opin Immunol. 2009; 21:10-6. [PubMed: 19223160]

22. Stutz A, Golenbock DT, Latz E. Inflammasomes: too big to miss. J Clin Invest. 2009; 119:350211. [PubMed: 19955661]

23*. Franchi L, Eigenbrod T, Munoz-Planillo R, Nunez G. The inflammasome: a caspase-1-activation platform that regulates immune responses and disease pathogenesis. Nat Immunol. 2009; 10:241-7. Good review about the inflammasome signaling. [PubMed: 19221555]

24. Villani A-C, Lemire M, Fortin G, Louis E, Silverberg MS, Collette C, Baba N, Libioulle C, Belaiche J, Bitton A, Gaudet D, Cohen A, Langelier D, Fortin PR, Wither JE, Sarfati M, Rutgeerts P, Rioux JD, Vermeire S, Hudson TJ, Franchimont D. Common variants in the NLRP3 region contribute to Crohn's disease susceptibility. Nat Genet. 2009; 41:71-76. [PubMed: 19098911]

25. Schoultz I, Verma D, Halfvarsson J, Torkvist L, Fredrikson M, Sjoqvist U, Lordal M, Tysk C, Lerm M, Soderkvist P, Soderholm JD. Combined Polymorphisms in Genes Encoding the Inflammasome Components NALP3 and CARD8 Confer Susceptibility to Crohn's Disease in Swedish Men. Am J Gastroenterol. 2009; 104:1180-1188. [PubMed: 19319132]

26. Lewis GJ, Massey DCO, Zhang H, Bredin F, Tremelling M, Lee JC, Berzuini C, Parkes M. Genetic association between NLRP3 variants and Crohn's disease does not replicate in a large UK panel. Inflammatory Bowel Diseases. 2010:n/a-n/a.

27. Roberts RL, Topless RKG, Phipps-Green AJ, Gearry RB, Barclay ML, Merriman TR. Evidence of interaction of CARD8 rs2043211 with NALP3 rs35829419 in Crohn's disease. Genes Immun. 2010; 11:351-356. [PubMed: 20182451]

28. He B, Xu W, Santini PA, Polydorides AD, Chiu A, Estrella J, Shan M, Chadburn A, Villanacci V, Plebani A, Knowles DM, Rescigno M, Cerutti A. Intestinal bacteria trigger T cell-independent immunoglobulin A(2) class switching by inducing epithelial-cell secretion of the cytokine APRIL. Immunity. 2007; 26:812-26. [PubMed: 17570691]

29. Xu W, He B, Chiu A, Chadburn A, Shan M, Buldys M, Ding A, Knowles DM, Santini PA, Cerutti A. Epithelial cells trigger frontline immunoglobulin class switching through a pathway regulated by the inhibitor SLPI. Nat Immunol. 2007; 8:294-303. [PubMed: 17259987]

30*. Hapfelmeier S, Lawson MA, Slack E, Kirundi JK, Stoel M, Heikenwalder M, Cahenzli J, Velykoredko Y, Balmer ML, Endt K, Geuking MB, Curtiss R 3rd, McCoy KD, Macpherson AJ. Reversible microbial colonization of germ-free mice reveals the dynamics of $\operatorname{IgA}$ immune responses. Science. 2010; 328:1705-9. Interesting study using germ-free mice to dissect the IgA function in the intestine. [PubMed: 20576892]

31. Ayabe T, Satchell DP, Wilson CL, Parks WC, Selsted ME, Ouellette AJ. Secretion of microbicidal [alpha]-defensins by intestinal Paneth cells in response to bacteria. Nat Immunol. 2000; 1:113118. [PubMed: 11248802] 
32. Kinnebrew M, Ubeda C, Zenewicz L, Smith N, Flavell R, Pamer E. Bacterial Flagellin Stimulates Toll-Like Receptor 5-Dependent Defense against Vancomycin-Resistant Enterococcus Infection. The Journal of Infectious Diseases. 2010; 201:534-543. [PubMed: 20064069]

33. Rumio C, Besusso D, Palazzo M, Selleri S, Sfondrini L, Dubini F, Menard S, Balsari A. Degranulation of Paneth Cells via Toll-Like Receptor 9. Am J Pathol. 2004; 165:373-381. [PubMed: 15277213]

34. Wehkamp J, Harder J, Weichenthal M, Schwab M, Schaffeler E, Schlee M, Herrlinger KR, Stallmach A, Noack F, Fritz P, Schroder JM, Bevins CL, Fellermann K, Stange EF. NOD2 (CARD15) mutations in Crohn's disease are associated with diminished mucosal alpha-defensin expression. Gut. 2004; 53:1658-64. [PubMed: 15479689]

35. Cash HL, Whitham CV, Behrendt CL, Hooper LV. Symbiotic bacteria direct expression of an intestinal bactericidal lectin. Science. 2006; 313:1126-30. [PubMed: 16931762]

36. Vaishnava S, Behrendt CL, Ismail AS, Eckmann L, Hooper LV. Paneth cells directly sense gut commensals and maintain homeostasis at the intestinal host-microbial interface. Proceedings of the National Academy of Sciences. 2008; 105:20858-20863.

37. Gong J, Xu J, Zhu W, Gao X, Li N, Li J. Epithelial-specific blockade of MyD88-dependent pathway causes spontaneous small intestinal inflammation. Clinical Immunology. 2010; 136:245256. [PubMed: 20452828]

38. Hampe J, Franke A, Rosenstiel P, Till A, Teuber M, Huse K, Albrecht M, Mayr G, De La Vega FM, Briggs J, Gunther S, Prescott NJ, Onnie CM, Hasler R, Sipos B, Folsch UR, Lengauer T, Platzer M, Mathew CG, Krawczak M, Schreiber S. A genome-wide association scan of nonsynonymous SNPs identifies a susceptibility variant for Crohn disease in ATG16L1. Nat Genet. 2007; 39:207-211. [PubMed: 17200669]

39. Rioux JD, Xavier RJ, Taylor KD, Silverberg MS, Goyette P, Huett A, Green T, Kuballa P, Barmada MM, Datta LW, Shugart YY, Griffiths AM, Targan SR, Ippoliti AF, Bernard E-J, Mei L, Nicolae DL, Regueiro M, Schumm LP, Steinhart AH, Rotter JI, Duerr RH, Cho JH, Daly MJ, Brant SR. Genome-wide association study identifies new susceptibility loci for Crohn disease and implicates autophagy in disease pathogenesis. Nat Genet. 2007; 39:596-604. [PubMed: 17435756]

40. Parkes M, Barrett JC, Prescott NJ, Tremelling M, Anderson CA, Fisher SA, Roberts RG, Nimmo ER, Cummings FR, Soars D, Drummond H, Lees CW, Khawaja SA, Bagnall R, Burke DA, Todhunter CE, Ahmad T, Onnie CM, McArdle W, Strachan D, Bethel G, Bryan C, Lewis CM, Deloukas P, Forbes A, Sanderson J, Jewell DP, Satsangi J, Mansfield JC, Cardon L, Mathew CG. Sequence variants in the autophagy gene IRGM and multiple other replicating loci contribute to Crohn's disease susceptibility. Nat Genet. 2007; 39:830-832. [PubMed: 17554261]

41. Cadwell K, Liu JY, Brown SL, Miyoshi H, Loh J, Lennerz JK, Kishi C, Kc W, Carrero JA, Hunt S, Stone CD, Brunt EM, Xavier RJ, Sleckman BP, Li E, Mizushima N, Stappenbeck TS, Virgin HW IV. A key role for autophagy and the autophagy gene Atg1611 in mouse and human intestinal Paneth cells. Nature. 2008; 456:259-263. [PubMed: 18849966]

42. Cadwell K, Patel KK, Komatsu M, Virgin HWt, Stappenbeck TS. A common role for Atg16L1, Atg5 and Atg7 in small intestinal Paneth cells and Crohn disease. Autophagy. 2009; 5:250-2. [PubMed: 19139628]

43**. Travassos LH, Carneiro LAM, Ramjeet M, Hussey S, Kim Y-G, Magalhaes JG, Yuan L, Soares F, Chea E, Le Bourhis L, Boneca IG, Allaoui A, Jones NL, Nunez G, Girardin SE, Philpott DJ. Nod1 and Nod2 direct autophagy by recruiting ATG16L1 to the plasma membrane at the site of bacterial entry. Nat Immunol. 11:55-62. The authors associate for the first time NOD proteins and autophagy. Very relevant paper since the innate immune receptor NOD2 and the autophagy protein ATG16L1 are associated to an increased susceptibility for Crohn's disease. [PubMed: 19898471]

44. Mayuzumi H, Inagaki-Ohara K, Uyttenhove C, Okamoto Y, Matsuzaki G. Interleukin-17A is required to suppress invasion of Salmonella enterica serovar Typhimurium to enteric mucosa. Immunology. 2010; 131:377-385. [PubMed: 20575990]

45. Ivanov, McKenzie BS, Zhou L, Tadokoro CE, Lepelley A, Lafaille JJ, Cua DJ, Littman DR. The orphan nuclear receptor RORgammat directs the differentiation program of proinflammatory IL-17+ T helper cells. Cell. 2006; 126:1121-33. [PubMed: 16990136] 
46**. Vijay-Kumar M, Aitken JD, Carvalho FA, Cullender TC, Mwangi S, Srinivasan S, Sitaraman SV, Knight R, Ley RE, Gewirtz AT. Metabolic syndrome and altered gut microbiota in mice lacking Toll-like receptor 5. Science. 2010; 328:228-31. Very interesting paper that links innate immunity and metabolism in TLR5 knock-out mice, for the first time. This study shows how TLR5 deficient mice have several biochemical functions impaired. [PubMed: 20203013]

47. Wolfs TG, Derikx JP, Hodin CM, Vanderlocht J, Driessen A, de Bruine AP, Bevins CL, Lasitschka F, Gassler N, van Gemert WG, Buurman WA. Localization of the lipopolysaccharide recognition complex in the human healthy and inflamed premature and adult gut. Inflamm Bowel Dis. 2010; 16:68-75. [PubMed: 20014022]

48**. Richardson WM, Sodhi CP, Russo A, Siggers RH, Afrazi A, Gribar SC, Neal MD, Dai S, Prindle T Jr, Branca M, Ma C, Ozolek J, Hackam DJ. Nucleotide-binding oligomerization domain-2 inhibits toll-like receptor-4 signaling in the intestinal epithelium. Gastroenterology. 2010; 139:904-17. 917, e1-6. Beautiful study showing how NOD2 inhibits TLR4-induced apoptosis in the small intestine of mouse newborns with necrotizing enterocolitis. [PubMed: 20580721]

49. Talbot S, Tötemeyer S, Yamamoto M, Akira S, Hughes K, Gray D, Barr T, Mastroeni P, Maskell DJ, Bryant CE. Toll-like receptor 4 signalling through MyD88 is essential to control Salmonella enterica serovar Typhimurium infection, but not for the initiation of bacterial clearance. Immunology. 2009; 128:472-483. [PubMed: 19930040]

50. Cook P, Tötemeyer S, Stevenson C, Fitzgerald KA, Yamamoto M, Akira S, Maskell DJ, Bryant CE. Salmonella-induced SipB-independent cell death requires Toll-like receptor-4 signalling via the adapter proteins Tram and Trif. Immunology. 2007; 122:222-229. [PubMed: 17490432]

51. Uematsu S, Fujimoto K, Jang MH, Yang B-G, Jung Y-J, Nishiyama M, Sato S, Tsujimura T, Yamamoto M, Yokota Y, Kiyono H, Miyasaka M, Ishii KJ, Akira S. Regulation of humoral and cellular gut immunity by lamina propria dendritic cells expressing Toll-like receptor 5. Nat Immunol. 2008; 9:769-776. [PubMed: 18516037] 


\section{SUMMARY}

- Innate immunity in the small intestine is critical since there is a large mucosal surface exposed to the commensal microflora and potential pathogens.

- The main strategies to control the luminal bacteria are the production of secretory IgA and antimicrobial molecules.

- Regulation of the antimicrobial strategies involves the intestinal epithelial cells, and the innate immune receptors (TLRs and NLRs).

- A better understanding of the events that regulate innate immunity in the small intestine will help to develop new therapies to protect the host against pathogens. 


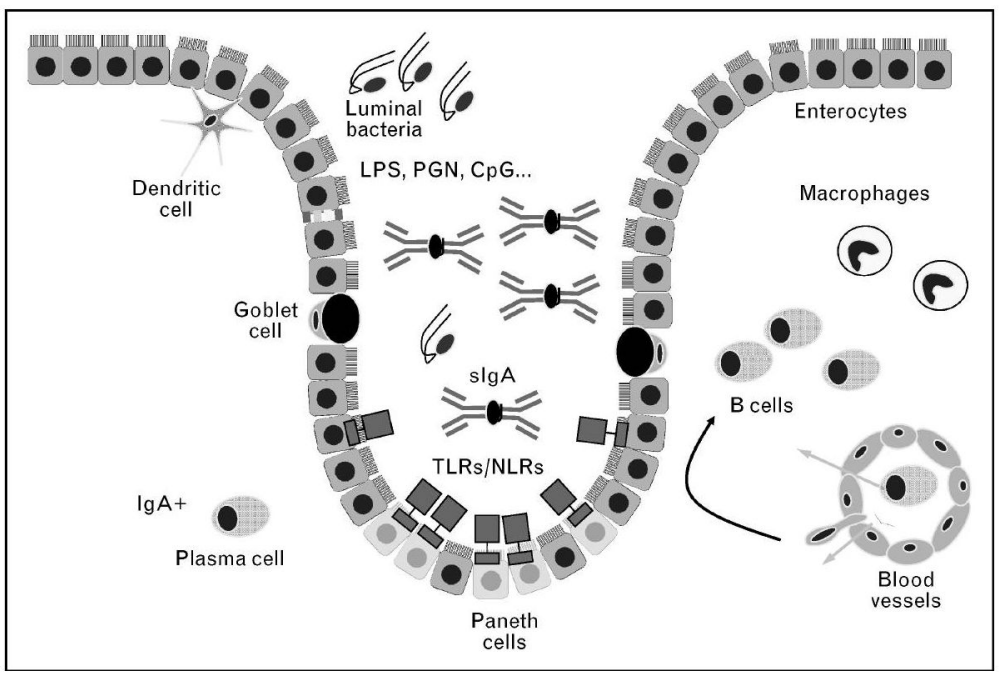

Figure 1. Innate immunity in the small intestine

The intestinal bacterial load is controlled by antimicrobial peptides and IgA secreted into the intestinal crypt. Paneth cells, situated in the base of the crypt, are the main producers of antimicrobial agents. IgA is produced by plasma cells located in the lamina propria, and is secreted to the lumen via transcellular transport. Innate immune receptors, TLRs and NLRs, are expressed in the intestinal epithelium and are the sensors for pathogen-associated molecular patterns. In the lamina propria, dendritic cells and macrophages function as antigen presenting cells. 